\title{
Thalassemia Premarital Screening Program: Public View, What has been Done, What Needs to be Done?
}

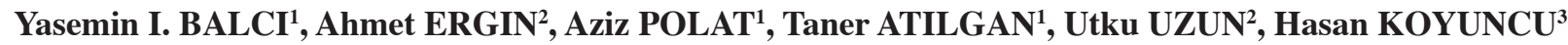 \\ ${ }^{1}$ Pamukkale University, Faculty of Medicine, Pediatric Hematology and Thalassemia Center \\ ${ }^{2}$ Pamukkale University, Faculty of Medicine, Department of Public Health \\ ${ }^{3}$ City Hemoglobinopathy Control Center of Regional Health Administration, Denizli, TURKEY
}

\begin{abstract}
Premarital screening (PMS) can be an important tool to detect of carriers of hemoglobinopathies. The aim of this study was to assess the knowledge and attitude of premarital couples about Thalassemia before PMS in Denizli province. This cross-sectional study was conducted between August-December 2013. The target population was all premarital couples who applied to the City Hemoglobinopathy Control Center during the designated period. A self-report questionnaire was completed by 501 participants. Most of the couples (91\%) strongly agreed with the importance of PMS program, that the program will contribute to a reduction in the prevalence of some genetic diseases. Approximately half of the couples (57.7\%) previously heard thalassemia and the hemoglobinopathy control program. The main source of information on thalassemia was TV, the internet, and newspapers. $53.2 \%$ of participants think "thalassemia trait" as a disease. $82.5 \%$ of participant had no idea about that or thought thalassemia is not contagious. Half of the participants (50\%) indicated that couples who have thalassemia can marry and have children. Approximately half of the participants reported that thalassemia passes down through families and consanguineous marriage increases the risk for having thalassemia. $41.6 \%$ of participants said thalassemia is a preventable disease. Multivariable analysis demonstrated that couples knowledge score about thalassemia positively correlated with age and educational status of the participants $(p=0.013$ and $p<0.001$, respectively). Knowledge in the couples about thalassemia was inadequate. Awareness of the public should be raised by an educational campaign in schools and health care services.
\end{abstract}

Keywords: Premarital screening, Thalassemia, Turkey

\section{ÖZET}

Evlilik Öncesi Talasemi Tarama Programı: Halkın Gözünden, Neler Yapılıyor, Neler Yapılmalı?'

Evlilik öncesi hemoglobinopati taraması, taşıyıııların saptanmasında önemli bir yoldur. Bu çalışmanın amacı Denizli bölgesindeki evlenecek çiftlerin, tarama programı öncesi Talasemi hakkında bilgi ve tutumlarını araştııımasıdır. Bu kesitsel çalışma Ağustos 2013 ve Aralık 2013 tarihleri arasında yürütüldü. Hedef popülasyon belirtilen tarihlerde Denizli Hemoglobinopati Kontrol Merkezi'ne başvuran tüm evlilik öncesi çiftler olarak belirlendi. Beşyüzbir katıımcıya anket uygulandı. Çiftlerin çoğu (\%91) evlilik öncesi Talasemi tarama programının önemli olduğunu ve bazı genetik hastalıkların sıkığını azaltacağını düşünmekte idi. \%57.7 oranında çift, daha önceden Talasemi ve hemoglobinopati kontrol programını duymuştu. Talasemi hakkında temel bilgi kaynağı televizyon, internet ve gazetelerdi. Katıımcıların \%53,2'si “Talasemi taşıyıclığını” hastalık olarak düşünmekte, \%82.5 ise talaseminin bulaşıcı olup olmaması konusunda bir fikre sahip değildi. Katıımcıların yaklaşık yarısı, talasemili çiftlerin evlenebileceği ve çocuk sahibi olabileceğini belirtti. \%50 katılımcı, Talaseminin ailesel geçiş gösterdiği ve akraba evliliklerinin Talasemi riskini arttırdığını bildirdi. \%41.6 katılımcı ise Talaseminin önlenebilir bir hastalık olduğunu ifade etti. Çok değişkenli analizler, çiftlerin Talasemi ile ilgili bilgi düzeyleri katılımcıların yaş ve eğitim durumu ile pozitif ilişkili olduğunu gösterdi (sırayla p=0.013 and p<0.001). Talasemi ile ilgili çiftlerin bilgi düzeyleri yeterli değildir. Toplumun farkındalığı okullarda ve sağlık kuruluşlarında yürütülen eğitim kampanyaları ile arttırımalıdır.

Anahtar Kelimeler: Evlilik öncesi tarama, Talasemi, Türkiye 


\section{INTRODUCTION}

Premarital screening (PMS) is one of the most important strategies for prevention of genetic disorders, congenital anomalies and several medical- psychosocial marital problems. ${ }^{1,2}$ Hemoglobinopathies are common genetic disorders in Mediterranean and Aegean area. Sickle cell anemia and thalassemia are major public health problem in this area, which can be prevented by PMS and genetic counseling or education. ${ }^{3}$ The PMS offers tests to couples who are planning to get married. The tests would help in the detection of carriers of hemoglobinopathies that can lead to affected offspring. ${ }^{4}$

The prevalence of beta thalassemia trait is $0.6-13 \%$ in Turkey. ${ }^{5}$ Parents of thalassemia major children experience considerable stress as a result of this chronic health problem and its high cost of treatment. In addition, the lack of availability of proper medical care in some regions and failure of compliance with supportive therapy represent important social problems of thalassemias. Population screening for heterozygous traits to identify carriers of thalassemia major is aimed at the prevention of these diseases. ${ }^{6,7}$ Therefore, the Ministry of Health passed a law in 1993 to start the screening, diagnosis, and treatment programs for hemoglobinopathies in some provinces where these conditions are common. The prevalence of beta thalassemia trait is $2.6 \%$ in Denizli province (5). Denizli is a developed and highly educated city located in Southwest Aegean region of Turkey. After the Ministry of Health law, a premarital hemoglobinopathy screening program was begun in 1995 in city of Denizli. Since 1995 hemoglobinopathy screening and education programs have became mandatory unmarried couples in Denizli. Further, public educational programs and symposiums on the subject were organized for awareness. ${ }^{5,8-10}$

The purpose of this study was to assess the current level of knowledge and attitudes of premarital couples about thalassemia in Denizli province in which the prevalence of beta thalassemia trait is $2.6 \%$.

\section{MATERIAL AND METHODS}

This cross-sectional study was conducted between August and December 2013. The population of the research was premarital couples who applied to the Hemoglobinopathy Control Center of Regional Health Administration for PMS in 2013. In
2012, 14767 people were applied to the center. A sample size of 374 applicants were calculate to be drawn from this population by using the formula $(\mathrm{n}=\mathrm{Nt} 2 \mathrm{pq} / \mathrm{d} 2(\mathrm{~N}-1)+\mathrm{t} 2 \mathrm{pq} ; \mathrm{N}=14767, \alpha=0.05, \mathrm{t}=$ $1.96, \mathrm{p}=0.50, \mathrm{q}=0.50, \mathrm{~d}=0.05)$. Eventually, 501 people were included in the study. This study was approved by the Pamukkale University Ethics Committee. Informed written consents were obtained from all couples before completing the questionnaires. A structured questionnaire with close-ended questions was designed by the authors following an extensive review of the literature on the knowledge of thalassemia. A self reporting questionnaire was given couples. The researchers gave brief explanation about the main aims of the study before distributing the questionnaires. The couples were assured that their participation was voluntary and all the information would be confidential. The questionnaire consisted of 2 main parts: the first part was on the socio-demographic characteristics including gender, age, education status, working status, parent's consanguinity, and family history of thalassemia. The second part tested the couple's knowledge regarding awareness of thalassemia, PMS program for thalassemia, and genetic counseling. After the questionnaire was completed, blood samples were taken each subject for complete blood count and hemoglobin electrophoresis.

\section{Statistical Analysis:}

Data were evaluated using SPSS for Windows (SPSS Inc., Chicago, IL, USA). Descriptive statistics were done as usual manner, and either the Mann-Whitney or Kruskal-Wallis tests were used to determine the statistical differences among means. The linear regression analysis was used to determine the association between knowledge score about thalassemia and independent variables. Knowledge score was calculated as the sum of the correct answers to the knowledge questions.

\section{RESULTS}

The total number of participants enrolled in the study was 501. Demographic characteristics of the couples are shown Table 1. There were 248 female participants $(49.5 \%)$. Their ages ranged from 17-42 years. It was observed that $77.3 \%$ were in age group of $17-28$ years, followed by $22.8 \%$ in $29-42$ years. Most of the participants (66.8\%) had a high school 
Table 1. Demographic characteristics of the couples

\begin{tabular}{ll} 
Characteristics & $\mathbf{n}(\%)$ \\
\hline $\begin{array}{l}\text { Gender } \\
\text { Women }\end{array}$ \\
Men & $248(49.5)$ \\
Age group & $253(50.5)$ \\
$17-22$ & \\
$23-28$ & $115(23)$ \\
$29-42$ & $272(54.3)$ \\
\end{tabular}

Educational status

High school or less $\quad 324$ (66.8)

Univercity

167 (33.2)

Working status

Yes

$372(75.2)$

No

$123(24.8)$

Living place

Rural

$230(46.3)$

City

$267(53.7)$

Consanguinity of parents

Yes

$57(11.4)$

No

$435(87.2)$

I don't know

$7(1.4)$

Consanguinity of couples

Yes

$27(5.4)$

No

$476(93.4)$

I don't know

$6(1.2)$

Status of having a screening

test for thalassemia

Yes

$42(8.6)$

No

or less education. $75.2 \%$ of couples were employed. Most of participants (53.7\%) were from the city center. Consanguinity between couple's parents was $11.4 \%$, while it is $5.4 \%$ in the couples. The vast majority of couples $(91.4 \%)$ did not have any previous hemoglobin electrophoresis for thalassemia. Couples knowledge status about thalassemia is shown in Table 2. Results of the study revealed that vast majority of couples $(91 \%)$ strongly agreed with the importance of PMS program, that the program will contribute to a reduction in the prevalence of some genetic diseases. Approximately half of the couples $(57.7 \%)$ previously heard thalassemia and the hemoglobinopathy control program. The main sources of information on thalassemia were TV $(22.4 \%)$, internet $(27.6 \%)$, newspaper $(62.1 \%)$, friends and fam-

\begin{tabular}{|c|c|}
\hline Questions & $n(\%)$ \\
\hline \multicolumn{2}{|c|}{ Do you think premarital screening is important? } \\
\hline Yes & $447(91.0)$ \\
\hline No & $44(9.0)$ \\
\hline \multicolumn{2}{|c|}{$\begin{array}{l}\text { Do you think premarital screening reduces } \\
\text { genetic diseases? (Thalassemia) }\end{array}$} \\
\hline Yes & $400(82.3)$ \\
\hline No & $25(5.1)$ \\
\hline I don't know & $61(12.6)$ \\
\hline \multicolumn{2}{|c|}{$\begin{array}{l}\text { Did you ever heard of thalassemia before? } \\
\text { (Hemoglobinopathy control program) }\end{array}$} \\
\hline Yes & $276(57.7)$ \\
\hline No & $202(42.3)$ \\
\hline \multicolumn{2}{|c|}{$\begin{array}{l}\text { Where did you heard of thalassemia? } \\
\text { (multiple choice) }\end{array}$} \\
\hline Internet & $75(27.6)$ \\
\hline TV/Radio & $61(22.4)$ \\
\hline Newspaper/Magazine & $33(12.1)$ \\
\hline School/Health Service & $80(29.4)$ \\
\hline Family/Friend & $157(57.7)$ \\
\hline \multicolumn{2}{|c|}{ Is "thalassemia trait" a disease? } \\
\hline Yes & $133(53.2)$ \\
\hline No & $40(16.0)$ \\
\hline I don't know & 77 (30.8) \\
\hline \multicolumn{2}{|l|}{ Is thalassemia contagious? } \\
\hline Yes & $43(17.5)$ \\
\hline No & $114(46.3)$ \\
\hline I don't know & $89(36.2)$ \\
\hline \multicolumn{2}{|c|}{$\begin{array}{l}\text { Could couples who have thalassemia trait } \\
\text { marry and have children with thalassemia? }\end{array}$} \\
\hline Yes & $122(50.0)$ \\
\hline No & $24(9.8)$ \\
\hline I don't know & $98(40.2)$ \\
\hline \multicolumn{2}{|c|}{ Does thalassemia pass down through families? } \\
\hline Yes & $107(44.0)$ \\
\hline No & $24(9.9)$ \\
\hline I don't know & $112(46.1)$ \\
\hline \multicolumn{2}{|c|}{$\begin{array}{l}\text { Does consanguineous marriage increases } \\
\text { the risk for having thalassemia? }\end{array}$} \\
\hline Yes & $104(42.1)$ \\
\hline No & $30(12.1)$ \\
\hline I don’t know & $113(45.7)$ \\
\hline \multicolumn{2}{|c|}{ Is thalassemia a preventable disease? } \\
\hline Yes & $101(41.6)$ \\
\hline No & $38(15.6)$ \\
\hline I don't know & $104(42.8)$ \\
\hline \multicolumn{2}{|c|}{ Does thalassemia have any treatment? } \\
\hline Yes & $114(46.9)$ \\
\hline No & $27(11.1)$ \\
\hline I don't know & $102(42.0)$ \\
\hline
\end{tabular}

ily $(57.7 \%)$, and school/ health services (29.4\%). $53.2 \%$ of participants think "thalassemia trait" as a disease. On the other hand, $17.5 \%$ of participants said thalassemia is contagious, $82.5 \%$ of participant had no idea about that or thought thalassemia is not contagious. Half of the participants (50\%) 


\begin{tabular}{|lll|}
\hline \multicolumn{2}{|l|}{ Table 3. Couples knowledge score about thalassemia } \\
\hline Variables & \multicolumn{1}{l|}{ Knowledge Score p value } \\
\hline Gender & & \\
Female & $4.53 \pm 2.68$ & 0.933 \\
Male & $4.48 \pm 2.89$ & \\
Age group & & \\
17-22 & $3.85 \pm 2.76$ & \\
$23-28$ & $4.32 \pm 2.74$ & 0.013 \\
$29-42$ & $5.43 \pm 2.72$ & \\
Educational status & & \\
High school or less & $3.57 \pm 2.90$ & $<0.001$ \\
University & $5.55 \pm 2.29$ & \\
Working status & & \\
Yes & $4.69 \pm 2.79$ & 0.053 \\
No & $3.82 \pm 2.68$ & \\
Living place & & \\
City & $4.81 \pm 2.71$ & 0.161 \\
Rural & $4.26 \pm 2.88$ & \\
& & \\
\end{tabular}

indicated that couples who have thalassemia can marry and have children; most of other half of the participants (40.2\%) had no idea. Approximately half of the participants reported that thalassemia passes down through families and consanguineous marriage increases the risk for having thalassemia. $41.6 \%$ of participants said thalassemia is a preventable disease; most of other half of the participants $(42.8 \%)$ had no idea. On the other hand, $46.9 \%$ of participants think that thalassemia is treatable; $42 \%$ of participants had no idea. Multivariable analysis demonstrated that couples knowledge score about thalassemia positively correlated with age and educational status of the participants $(\mathrm{p}=0.013$ and $\mathrm{p}<$ 0.001 , respectively) (Table 3 and 4).

\section{DISCUSSION}

The results of this study clearly showed that the participants are aware of the possible positive effects of PMS programs and premarital screening reduces genetic diseases. But their knowledge was inadequate about its various aspects such as what thalassemia trait is, whether thalassemia trait is contagious, whether thalassemia pass down through families, whether thalassemia is a preventable disease, and

\begin{tabular}{|lll|}
\hline $\begin{array}{l}\text { Table 4. Association between knowledge } \\
\text { thalassemia and variables }\end{array}$ & score about \\
\hline Variables & $\mathbf{B}(\% \mathbf{9 5} \mathbf{~ C l})$ & $\mathbf{p}$ value \\
\hline Age & $0.145(0.016-0.182)$ & 0.020 \\
Educational status & $0.344(1.236-2.598)$ & $<0.001$ \\
& & \\
\hline
\end{tabular}

whether thalassemia have any treatment. These results agree with the results of several other studies done in different countries. An educational program conducted among female university students found that students' attitude was positive $(81.8 \%$ of students in the Pre-test and $85.9 \%$ in the Post-test approved the importance of PMS). ${ }^{11}$ Another study demonstrated there was positive attitude of Saudi population towards the program and the majority of participants agreed that the PMS program should apply to all couples in all regions of Saudi Arabia. ${ }^{11}$ However, Ibrahim et al. ${ }^{12}$ demonstrated that unmarried female students' knowledge about PMS program was low in the Pre-test; $80.9 \%$ of students obtained a poor score while only $19.1 \%$ obtained fair and satisfactory scores. Al Kindi et al. ${ }^{4}$ show that university students were aware about PMS program, but their knowledge was low. This result is similar with other Syrian and Saudi Arabian studies. ${ }^{13,14}$ Another study which explored the impact of the PMS program and genetic counseling on couples at risk for thalassemia and sickle cell anemia in an area of the country with high hemoglobinopathy prevalence found a lack of awareness about genetic diseases and a misunderstanding of the impact of genes on health. ${ }^{15}$

In our study, the majority of participants think that consanguineous marriage increases genetic diseases. On the other hand, nearly half of participants could not know whether consanguineous marriage increases the risk for having thalassemia. A previous study found that $84 \%$ of students believed that consanguinity can increase the risk for genetic diseases. ${ }^{16}$ Another study showed that $89.6 \%$ of students strongly agreed that consanguinity can increase the risk of hereditary diseases. ${ }^{12}$ However, in this study, consanguinity of couples and their parents (who lives in Denizli, an Aegean city with a high socio-cultural level) were low (\%5.4, \%11.4), it is quite interesting that we couldn't receive cor- 
rect answers, as much we expected, to that question; "Do you think consanguineous marriage increases genetic diseases?" This finding may be interpreted as insufficient public awareness on thalassemia in this population.

The majority of participants did not have any screening for thalassemia previously in this study. PMS is a mandatory procedure before marriage in Denizli. Other studies from Saudi Arabia and Oman reported that making PMS procedure before marriage was favored. ${ }^{4,17}$ In Denizli, preventive and therapeutic/ curative health practices are advanced compared to many regions of Turkey. However, 91.4\% of couples did not have any previous screening test for thalassemia, so it is obvious that health institutions did not give enough importance to that issue. On the other hand, couples did not know their status of thalassemia trait before marriage, so it points that more community health education should be provided. Undoubtly, PMS is an important practice, but couples can break up or have some problems if they learn that both have thalassemia trait. Therefore, this negative attitude could be improved by intense health education especially for those at high risk of transmitting thalassemia trait.

The present study showed that approximately half of the couples previously heard thalassemia and the hemoglobinopathy control program. T.V, internet, and newspaper were cited as the most common source of information regarding PMS, followed friends and family. Ibrahim et al. ${ }^{12}$ show that the main sources of information on genetic diseases were friends and family. Al Kindi et al. ${ }^{4}$ reported that nearly one third of the participants' source of information on PMS was media. Other studies shown that TV was the most common source of knowledge (18). Dabbous et al. ${ }^{19}$ found that radio and television were the most common reported means of health education $(65 \%)$. We think that media (TV, internet, newspaper) plays a prominent role in enlightening the general public regarding the PMS program. In our study, school and health services came in third source of information about PMS. This result indicates that school and health services are not efficient as expected in spreading information on PMS. Schools education program can be improved by employing different systems including PMS program in the school's curriculum and organizing lectures about thalassemia and the hemoglobinopathy control program. Health care services also need to make more effort on PMS and thalassemia. When physicians diagnose thalassemia trait, they need to investigate entire family about thalassemia. Doctors and nurses should make further explaining for PMS program and thalassemia.

Our study demonstrated that education was the first predictor of a high knowledge score. This result coincides with the results of studies from Jeddah and Emirates. ${ }^{18,20}$ Knowledge score increases with age significantly, and working status has a borderline significance. Previous study which organized unmarried female students found that the predictors of student's knowledge scores included: being a health science student, age $>20$ years, family income $>$ $10.000 \mathrm{SR} /$ month. $^{12}$ These results revealed that PMS program and education about thalassemia is very important and this education program also should be given in younger ages.

There are several limitations in this study. Main limitation is the time frame of the study. We included everybody who consented and applied the Center during the study period which was only a 4-month duration. However, we have no information whether or not the participants in this study differ in any way from the other time applicants of the Center. Also, cross-sectional design of the study may be argued as a weakness of the study. However, this study may be used a baseline for follow-up studies on the topic.

Our study demonstrated that most of the couples have a positive attitude toward PMS but their knowledge was inadequate. Awareness of the public should be raised on the benefits of PMS with educational campaigns in schools and health care services.

\section{REFERENCES}

1 Al Sulaiman A, Suliman A, Al Mishari M, et al. Knowledge and attitude toward the hemoglobinopathies premarital screening program in Saudi Arabia: population-based survey. Hemoglobin 32: 531-538, 2008.

2 Mitwally $\mathrm{HH}$, Abd El-Rahman DA, Mohamed NI. Premarital counseling: view of the target group. J Egypt Public Health Assoc 75: 31-51, 2000.

3 Jain BB, Roy RN, Ghosh S, et al. Screening for thalassemia and other hemoglobinopathies in a tertiary care hospital of West Bengal: implications for population screening. Indian J Public Health 56: 297-300, 2012. 
4 Al Kindi R, Al Rujaibi S, Al Kendi M. Knowledge and attitude of university students towards premarital screening program. Oman Med J 27: 291-296, 2012.

5 T.C. Saglik Bakanligi ACSAP Genel Mudurlugu. Hemoglobinopati kontrol programi, Canatan D, Aydinok Y (eds). Talasemi ve Hemoglobinopatiler. Antalya, Retma Yayincilik Ltd., 2007: 29-34.

6 Keskin A, Türk T, Polat A, Koyuncu H, Saracoglu B. Premarital screening of beta-thalassemia trait in the province of Denizli, Turkey. Acta Haematol 104: 31-33, 2000.

7 Motulsky AG. Screening for genetic diseases. N Engl J Med 336: 1314-1316, 1997.

8 Canatan D, Aydinok Y, Kilinç Y, et al.National thalassemia prevention campaign: the talotPr project. Turk J Haematol 30: 91-92, 2013

9 Canatan D. Dünyada ve Türkiye'de Talasemi ve anormal hemoglobinler, Canatan D, Aydinok Y (eds). Talasemi ve Hemoglobinopatiler. Antalya, Retma Yayincilik Ltd., 2007: 1119.

10 Kemahli S, Acar A. Talasemide egitim. Canatan D, Aydinok Y (eds). Talasemi ve Hemoglobinopatiler Antalya, Retma Yayincilik Ltd., 2007: 35-38.

11 Alam AA. Perception of female students of King Saud University towards premarital screening. J Family Community Med 13: 83-88, 2006.

12 Ibrahim NK, Al-Bar H, Al-Fakeeh A, et al. An educational program about premarital screening for unmarried female students in King Abdul-Aziz University, Jeddah. J Infect Public Health 4: 30-40, 2011.

13 Gharaibeh H, Mater FK. Young Syrian adults' knowledge, perceptions and attitudes to premarital testing. Int Nurs Rev 56: 450-455, 2009.

14 Al-Aama JY, Al-Nabulsi BK, Alyousef MA, et al. Knowledge regarding the national premarital screening program among university students in western Saudi Arabia. Saudi Med J 29: 1649-53, 2008.
15 Al Sulaiman A, Saeedi M, Al Suliman A, Owaidah T. Postmarital follow-up survey on high risk patients subjected to premarital screening program in Saudi Arabia. Prenat Diagn 30: 478-481, 2010.

16 Al-Odaib AN, Abu-Amero KK, Ozand PT, Al-Hellani AM. A new era for preventive genetic programs in the Arabian Peninsula. Saudi Med J 24: 1168-1175, 2003.

17 Al-Kahtani $\mathrm{NH}$. Acceptance of premarital health counseling in riyadh city, 1417h. J Family Community Med 7: 27-34, 2000.

18 Ibrahim NK, Bashawri J, Al Bar H, et al. Premarital Screening and Genetic Counseling program: knowledge, attitude, and satisfaction of attendees of governmental outpatient clinics in Jeddah. J Infect Public Health 6: 41-54, 2013.

19 Dabbous NI, Abouzeid HM, Tayeln KY, et al. Knowledge and attitude about premarital counseling among a group of Alexandria University students; a comparative study. Bulletin of the High Institute of Public Health 25: 114-120, 1995.

20 Al-Gazali LI. Attitudes toward genetic counseling in the United Arab Emirates. Community Genet 8: 48-51, 2005.

\section{Correspondence}

Dr. Yasemin IŞIK BALCI

Pamukkale Üniversitesi Tıp Fakültesi

Çocuk Hematoloji Bilim Dalı

Kınıkl, DENIZLi / TURKEY

Tel: (+90.532) 5477179

e-mail: dryibalci@gmail.com 